
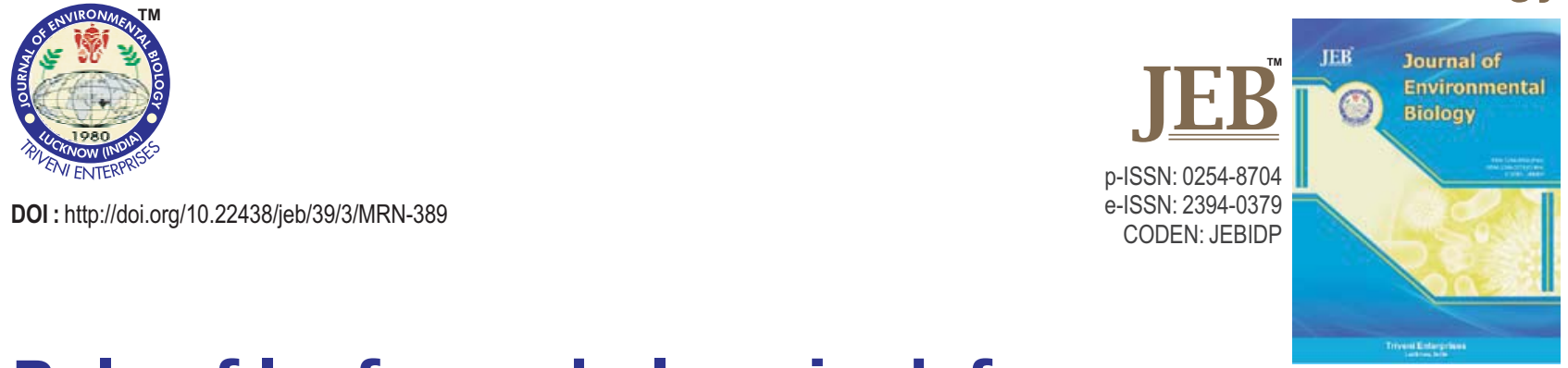

\title{
Role of leaf morphology in defense against sterility mosaic disease of pigeonpea
}

\section{Authors Info}

L. Manjunatha ${ }^{1,3 *}$, H.K. Ramappa ${ }^{2}$, and K.T. Rangaswamy ${ }^{3}$

${ }^{1}$ Division of Crop Protection, Indian Institute of Pulses Research,

Kanpur-208 024, India

${ }^{2}$ AICRP (Pigeonpea), ZARS, UAS, GKVK, Bangalore-560 065, India

${ }^{3}$ Department of Plant Pathology, University of Agricultural Sciences, Bangalore-560 065, India

${ }^{*}$ Corresponding Author Email : manjupath@gmail.com

Key words

Emaravirus

Leaf morphology

Pigeonpea

Sterility mosaic virus

Publication Info

Paper received : 30.10 .2016

Revised received : 12.06.2017

Re-revised received : 12.09 .2017

Accepted : 27.09.2017

\begin{abstract}
Aim : Sterility mosaic disease is an emerging viral disease of pigeonpea, caused by Pigeonpea sterility mosaic virus, belongs to the newly established genus Emaravirus and transmitted by eriophyid mite-Aceria cajani Channa Basavanna causing $>90$ per cent yield loss in India. Therefore, the host range of virus and leaf characters were studied to identify the host preference and mechanism of resistance existing in pigeonpea cultivars against mite vector to develop stable resistant cultivars against sterility mosaic virus of pigeonpea.
\end{abstract}

Methodology: A study was conducted on host range through sap inoculation of different plant species and leaf morphological study. Previously identified sterility mosaic virus resistant and moderately resistant and susceptible genotypes were used for leaf characters study. The leaf cross and free-hand sectioning technique was followed using double-sided razor blade for leaf characters study. The measurements were taken after observing sections in stereo binocular microscope.

Results : Among the host plants tested, N. benthamiana was identified as test plant for identification of Pigeonpea sterility mosaic virus. Host preference for Pigeonpea sterility mosaic virus through sap inoculation revealed that Pigeonpea sterility mosaic virus-B isolate had limited host range and was able to infect only to Cajanus cajan[ICP 8863(Maruthi)], Phaseolus vulgaris and N. benthamiana and were confirmed by DAC-ELISA. Morphological traits such as thickness of cuticle, epidermis, number and length of leaf hairs of resistant cultivars (ICP-7035 and HY 3C) revealed significant difference compared to susceptible cultivars ICP-2376, ICP-8863 and TTB-7.

Interpretation: Host range study of sterility mosaic disease confirmed that Pigeonpea sterility mosaic virus had narrow host preference and this would help in formulating agronomic system in diseased localities and utilizing as a component in the IDM. In resistant cultivars higher thickness of cuticle, epidermis, more number and length of leaf hairs are possibly involved in vector mediated resistance. These results would help in development of stable and broad based resistance against sterility mosaic disease of pigeonpea.
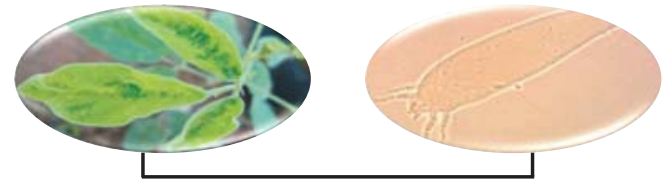

Sterility Mosaic Disease of pigeonpea an emerging viral disease caused by PPSMV, transmitted by eriophyid mite Aceria cajani

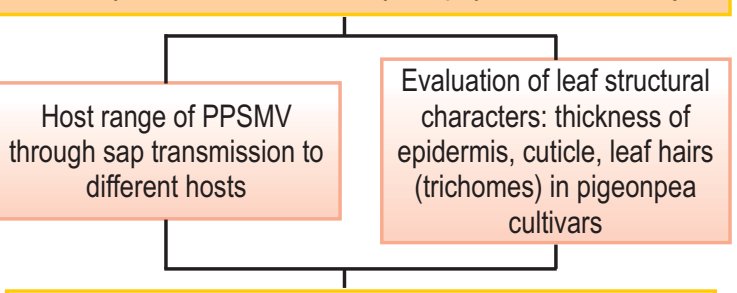

$N$. benthamiana is the best diagnostic host for PPSMV and infects brinjal, frenchbean, pigeonpea only. Cuticle thickness, low density of leaf hairs disrupts mite vector multiplication

$$
\downarrow
$$

Host range study would help in formulating agronomic system and can be utilized in IDM. Leaf morphological traits are involved in vector mediated resistance against sterility mosaic disease 


\section{Introduction}

Sterility mosaic disease is considered as a major biotic constraint in pigeonpea production and leads to heavy economic losses due to devastating effect on flowering and pod set. This disease alone causes yield loss to the extent of over US $\$ 300$ million (Kannaiyan et al., 1984) and $90 \%$ of the crop would be lost if it occurs at early stage (<45days) of the crop growth (Singh and Rathi, 1994; Bhaskaran and Muthiah, 2005). This is a matter of concern since the domestic and global demand of pigeonpea is rapidly increasing. This disease also known as the "green plague of pigeonpea" is caused by Pigeonpea Sterility Mosaic Virus (PPSMV) (Jones et al., 2004) and belongs to the newly established genus Emaravirus (Muehlbach and Mielke-Ehret, 2011). This genus includes five-segmented (Pigeonpea sterility mosaic virus -1), six-segmented (Pigeonpea sterility mosaic virus -2 ), negative-single stranded RNA viruses with enveloped, double membrane bodies (DMBs) and approximately spherical particles of 80-200 nm in diameter (Elbeaino et al., 2013; 2014; 2015). The virus is naturally transmitted by the vector eriophyid mite-Aceria cajani Channa Basavanna (Seth, 1962; Kannaiyan et al., 1984) and same virus was also transmitted experimentally to herbaceous hosts ( $N$. benthamiana and N.clevelandii) by sap inoculation (Kumar et al., 2002) but not transmitted through seed, pollen or soil (Reddy et al., 1998). This disease was first reported from Pusa, Bihar state (Mitra, 1931). The yield losses vary with the cultivars and age at which infection occurs. Occurrence, emergence and increased incidence of Pigeonpea sterility mosaic virus in the Indian sub-continent during the recent years have been attributed to the emergence of new strain Pigeonpea sterility mosaic virus-2 (Elbeaino et al., 2015).

The symptoms of sterility mosaic disease depend on the type of genotype (Ghanekar et al., 1992) and are usually of three types (Fig 1): complete sterility, partial sterility and ring spot on cv. ICP 2376 (Reddy et al., 1990). Reddy et al. (1993) have also reported the occurrence of five strains (Bangalore, Patancheru, Coimbatore, Badnapur and Doli isolates) of Pigeonpea sterility mosaic virus in India. Among the five strains, Bangalore isolate is a highly virulent strain as it produces slightly peculiar symptoms (severe mosaic) as compared to other Pigeonpea sterility mosaic virus isolates (mild mosaic and ring spots) (Kulkarni et al., 2003).

Large number of plant species are getting infected by diverse plant pathogens (Farr et al., 2004), but the number with which a pathogen interacts in a local plant community is generally much lower (Thompson, 2005). However, we have limited abilities to predict which species within a plant assemblage are most likely to be susceptible to a particular pathogen. Host selection in infection helps in prediction of plant disease epidemics and management of the plant disease and their risk involved in spread of pathogens and seed materials. Therefore, conducting host range study is essential to identify the phylogenetic limit of Pigeonpea sterility mosaic virus in causing disease across the plant species.

Management of sterility mosaic disease is a major challenge to minimize yield reduction in pigeonpea. Management of the disease using chemical methods has been found effective, but is non- economical and non-ecofriendly (Nene et al., 1989). Therefore, in-order to impart broad based resistance by combining of vector resistance in addition to host resistance is most important for sterility mosaic disease control. Till date, the exact mechanism of resistance has not been characterised. However, diverse mechanisms presumed to govern resistance to sterility mosaic disease resistance have been attributed to either the pathogen or to the vector or both (Reddy et al., 1995). Tiny hair-like structures called trichomes on leaf are part of the plant defense mechanisms that may confer resistance to some herbivore pests (Hall et al., 2017). Sharma et al. (2015) identified the multi-environment (broad based) stable resistances of the pigeonpea genotypes against different isolates of sterility mosaic pathogens. Secondary metabolites, morphological, anatomical features and nutritional status etc also contribute to resistance (Krips et al., 1999). Control of eriophyid mites using acaricides is often ineffective because of the small sized and may feed under plant protective structures such as glandular hairs. Host plant resistance may be genetic or ecological. If genetic, it may be due to simple or combination of mechanisms like antixenosis, antibiosis and tolerance. Leaf morphological characters have positive or negative influence on their herbivores (Krips et al., 1999). The type (thin or thick) of trichomes, their orientation, density and length have been well correlated with reduced insect damage in several crops (Peter et al., 1995). Likewise, Durmuskahya et al. (2015) and Gucel (2015) reported the significance of anatomical structures in many crop plants. In the present study, host preference of the virus and many leaf morphological features with their degree of association linked to sterility mosaic disease resistance were studied.

\section{Materials and Methods}

Host range studies/Bioassay : The bioassay study was conducted following sap transmission to 41 plant species belonging to eight families (Amaranthaceae, Asteraceae, Chenopodiaceae, Cucurbitaceae, Leguminaceae, Solanaceae and Malvaceae) to find out the host range of Pigeonpea sterility mosaic virus of pigeonpea. Plant species belonging to different families' viz., Amaranthaceae, Chenopodiaceae, Cucurbitaceae, Leguminaceae, Solanaceae, Asteraceae with ten plants each were used for host range/bioassay studies. Test plants were raised from healthy seeds in earthen pots containing the mixture of steam-sterilized soil, sand and compost in 2:1:1 ratio. (VNV) and maintained in an insect free glass house. Plants from each test species were inoculated with the sap extracted from virus infected pigeonpea leaves by conventional leaf rubbing method using 0.05 $\mathrm{M}$ phosphate buffer $\mathrm{pH} 7.0$ containing $0.1 \% \beta$-mercaptoethanol 

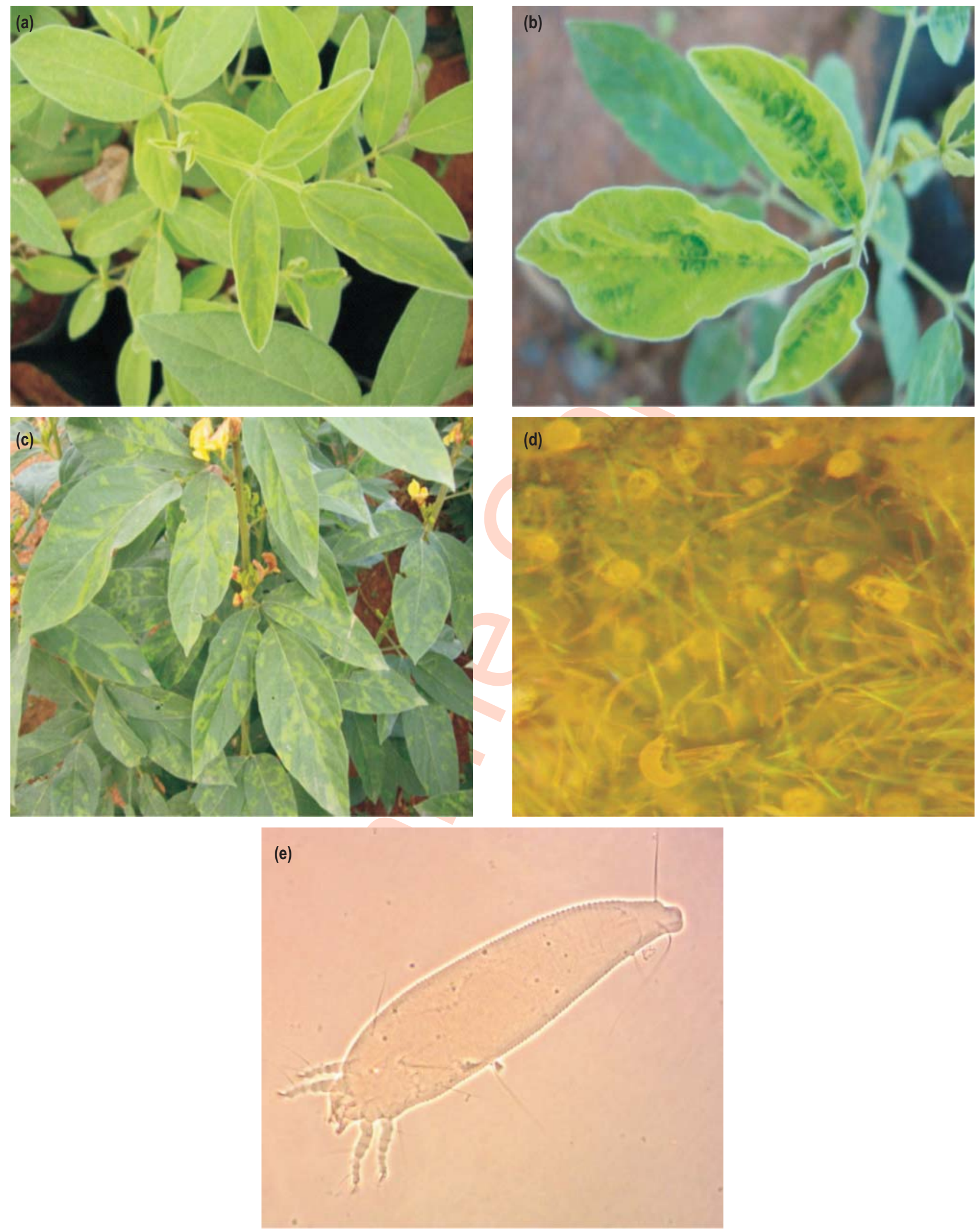

Fig. 1 : (a) Mild mosaic; (b) Severe mosaic; (c) Ring spot symptoms of SMD of pigeonpea; (d) Eriophyid mite, Aceria cajani on leaf surface(Arrow mark) and (e) Eriophyid mite, Aceria cajani (2 pairs of legs) slide specimen at 40X microscope 

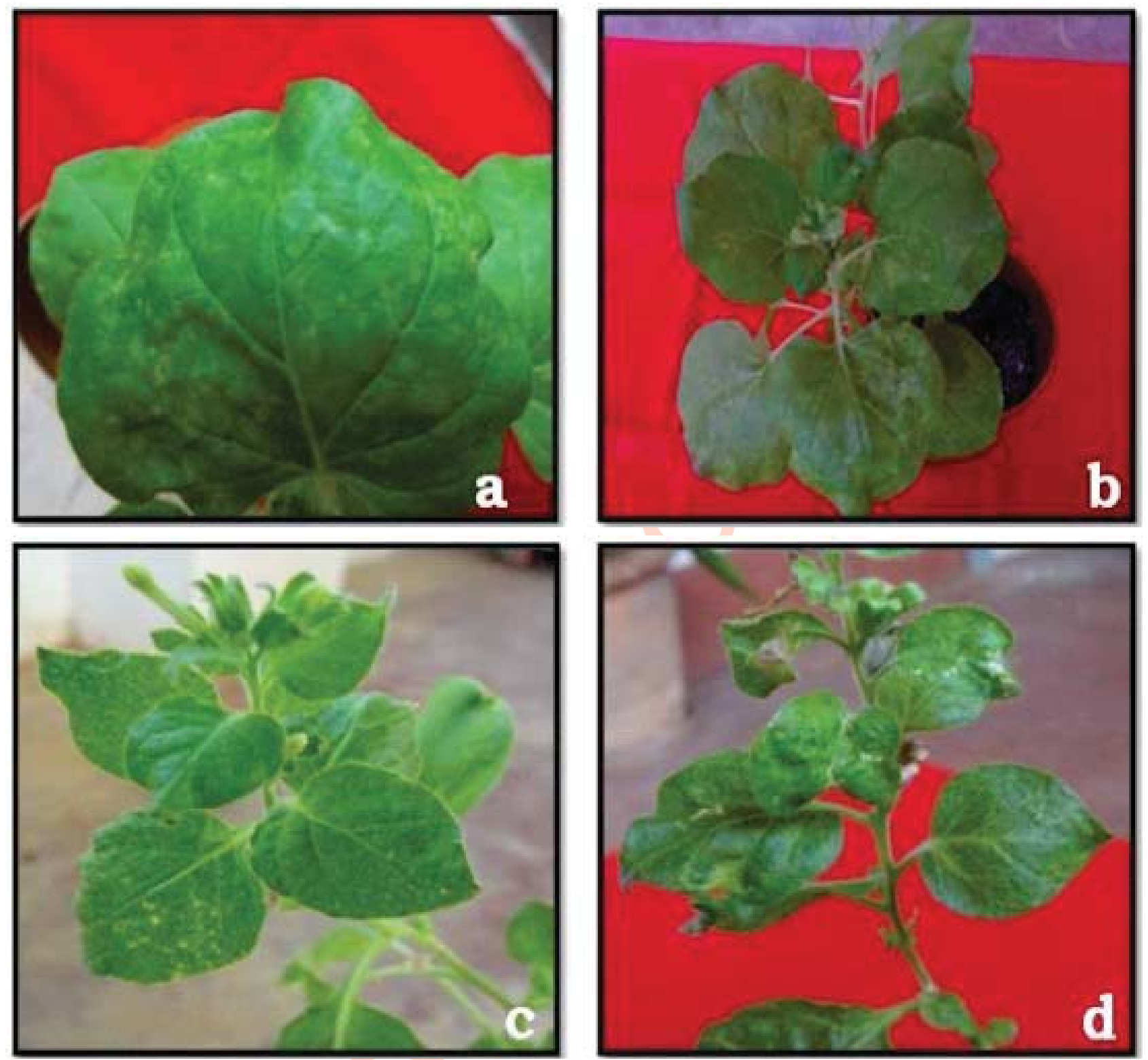

Fig. 2 : The PPSMV inoculated Nbenthamiana plants showing chlorotic flecks (a, b); Interveinal chlorosis and necrosis(c); Mosaic and necrosis (d)

and celite ${ }^{\circledR} 50$ (Sigma Aldrich) was used as an abrasive to make sub lethal wounds on leaves. All leguminous plants (French bean, cowpea, mungbean, urdbean) were inoculated on primary leaves before the emergence of first trifoliate leaf. The host range studies were conducted by raising seedlings of various plant species of tobacco and Chenopodium by inoculating them at 6-8 leaf stage, whereas cucurbits were inoculated at primary leaf stage and others at 2-4 leaf stage. The inoculated host plants were kept for observations in glass house for about 6 weeks. All inoculated plants were checked for virus by assay on N. benthamiana and also by using DAC-ELISA.

Leaf morphological features: The present study was attempted to understand the role of structural physical barriers, such as cell wall, thickness of cuticle and epidermal cell wall, length and number of leaf hair on susceptible, resistant and moderately resistant genotypes [ICP-7035(R), Hy-3C (MR), ICP 8863(S), ICP 2376(S) and TTB-7(S)]. From five genotypes; upper, middle and lower canopy were collected from 2-month old plants from same position from three test plants of each genotype. For leaf cross sectioning, free-hand sectioning technique was followed using double-sided razor blade (Ruzin, 1999). The fine vertical leaf sections were obtained from the central portion of the leaf embedded and fixed in resin, and thin sections were made using microtome. Each cutting was bleached with water and sodium hypochlorite 5 per cent mixture (1:1) for 15 min and rinsed with 
sterile distilled water for 10 minutes on a glass slide. Finally, it was mounted into 1:1 mixture of water and glycerine for microscopic observation. The measurements were taken after observing sections in stereo binocular microscope at 10X and 40X magnification attached with Progress@capture Pro 2.8.8JENOPTIK/Optical system. Based on visual observations under the microscope, various parameters of leaf like total leaf thickness, thickness of upper and lower epidermis, thickness of the cuticle (epidermal cell wall) upper and lower epidermis, number of leaf hair and length of leaf hairs in upper and lower epidermis/10 $\mu \mathrm{m}$ area were taken using ocular and stage micrometer. The average mean values of all leaf morphological traits data were subjected to statistical analysis employing complete randomized design using statistical software MSTATC and curated with appropriate transformations such as arcsine and square root transformation for above mentioned traits.

\section{Results and Discussion}

The sap inoculation of Pigeonpea sterility mosaic virus was done on forty one plant species of different family. Among the inoculated plant species, N. benthamiana recorded $100 \%$ transmission and observed the symptoms such as vein clearing, mild chlorotic flecks on apical leaves, mosaic in early stages and later coalesced to form large necrotic patches of 2-4 mm at 45 days after inoculation. However, prominent symptoms appeared at 70 days after inoculation (Fig. 2). The symptom such as mosaic and veinal chlorosis on Phsaeolus vulgaris and interveinal necrosis with disappearance of symptoms over the age was observed on $S$. melongena. The virus was detected in DACELISA, only $N$. benthamiana showed high absorbance value compared to other three hosts. The host range results of Pigeonpea sterility mosaic virus revealed that hosts found in the vicinity of pigeonpea field and many other plant species did not show any positive reaction to sap transmission of Pigeonpea sterility mosaic virus and DAC-ELISA test. In sap transmission, Pigeonpea sterility mosaic virus was unsuccessful infecting local lesion hosts but it was able to infect $N$. benthamiana, Phaseolus vulgaris, Solanum melongena only. These results showed that Pigeonpea sterility mosaic virus had very limited host infection and was able to infect pigeonpea cv.ICP 8863 (showing mosaic with reduced leaf size in the new leaf and soon plant die), $N$. benthamiana, P. vulgaris and Solanum melongena (Fig 2). These results are supported by Kumar et al. (2002) who successfully transmitted Pigeonpea sterility mosaic virus experimentally by mechanical transmission to Nicotiana benthamiana and $N$. clevelandii from the fresh leaf sap obtained from sterility mosaic disease infected pigeonpea. Therefore, $N$. benthamiana was identified as a test plant for Pigeonpea sterility mosaic virus.

Mechanical transmission of Pigeonpea sterility mosaic virus was achieved from pigeonpea to $N$. benthamiana with difficulty and expressed systemic symptoms at 45 days after inoculation. Only $40 \%$ sap transmission was achieved on other crops, except $N$. benthamiana. Inconsistency in sap transmission may be due to instability of Pigeonpea sterility mosaic virus due to high secondary metabolites present in the pigeonpea leaf sap that might be precipitated with viral protein and nucleic acids. Moreover, pigeonpea is a woody plant containing high polyphenolic and alkaloid complexes that might interfere with the virus infectivity (Kumar et al., 2002). Restricted host ranges of plant pathogens are thought to help in maintaining plant diversity in forest community (Packer and Clay, 2000). Large number of plant species are infected by diverse plant pathogens (Farr et al., 2004), but the number with which a pathogen interacts in a local plant community is generally much lower (Thompson, 2005). Usual understanding is that the plant species which are closely related should be possibly susceptible to the same pathogens than evolutionarily distant plant species. This might be due to the regulation and interactions of the pathogens with the plants are phylogenetically conserved at morphological and bio-chemical levels (Farrell, 2001). The limited host range of Pigeonpea sterility mosaic virus might be due to various defensive enzymes which were possibly expressed during virus inoculation, which needs further research to understand completely. Some leaf exudates also contain secondary metabolites and alkaloids which interfere with virus multiplication, lowering the chances of introducing virus into plant system, and thereby reducing the disease incidence.

The most feasible and cost effective means of controlling sterility mosaic disease is breeding for pigeonpea cultivars that are broad based and stable in resistance to the disease. But adequate levels of sterility mosaic disease resistance genotypes/cultivars are scarce in the cultivated pigeonpea gene pool (Kulkarni et al., 2003). Therefore, the previously identified susceptible (TTB 7, ICP 8863 and ICP 2376), moderately resistant (Hy-3C) and field resistant (ICP-7035) cultivars were studied structurally to understand the mechanism of resistance existing if any to the mite vector Aceria cajani.

Total leaf thickness of pigeonpea cultivars exhibited significant differences between the resistant, moderately resistant and susceptible cultivars. The maximum leaf thickness was observed in young, middle and old leaves of ICP 7035 cultivar with $142.02 \mu \mathrm{m}, 193.35 \mu \mathrm{m}$ and $232.60 \mu \mathrm{m}$, whereas it was minimum in susceptible cultivar (ICP 8863) with $79.35 \mu \mathrm{m}$ in young, $156.34 \mu \mathrm{m}$ and $208.64 \mu \mathrm{m}$ in middle and old leaves, respectively. Maximum thickness of upper epidermis was observed in the young $(18.62 \mu \mathrm{m})$, middle $(29.3 \mu \mathrm{m})$ and old $(29.65 \mu \mathrm{m})$ leaves of ICP-7035 as compared to cultivars ICP 2376, ICP 8863 and TTB-7. However, maximum lower epidermal thickness was observed in the resistant cultivar ICP 7035, wherein young, middle and old leaves recorded thickness of $11.34 \mu \mathrm{m}, 18.34 \mu \mathrm{m}$ and $21.00 \mu \mathrm{m}$, respectively. The susceptible cultivars, (ICP 8863 and ICP 2376) recorded minimum thickness of epidermis with $7.33 \mu \mathrm{m}$ in young leaves and $8.67 \mu \mathrm{m}$ in old leaves of ICP 2376 (Table 1). Thickness of upper epidermis of the pigeonpea leaves showed significant differences among resistant 
Table 1 : Leaf structural properties of PPSMV resistant/moderately resistant/susceptible pigeonpea cultivars

\begin{tabular}{|c|c|c|c|c|c|c|c|c|c|c|}
\hline \multirow[t]{2}{*}{ Genotype } & \multirow[t]{2}{*}{ Stages } & \multirow[t]{2}{*}{$\begin{array}{l}\text { Total leaf } \\
\text { thickness }(\mu \mathrm{m})\end{array}$} & \multicolumn{2}{|c|}{$\begin{array}{l}\text { Thickness of } \\
\text { epidermis }(\mu \mathrm{m})\end{array}$} & \multicolumn{2}{|c|}{$\begin{array}{l}\text { Thickness of epidermal } \\
\text { cuticle }(\mu \mathrm{m})\end{array}$} & \multicolumn{2}{|c|}{$\begin{array}{l}\text { Length of leaf } \\
\text { hairs }(\mu \mathrm{m})\end{array}$} & \multicolumn{2}{|c|}{$\begin{array}{l}\text { Number of leaf hairs/ } \\
10 \mu \mathrm{m} \text { area }\end{array}$} \\
\hline & & & Upper & Lower & Upper & Lower & Upper & Lower & Upper & Lower \\
\hline \multirow[t]{3}{*}{ ICP-7035(R) } & Young & 142.02 & 18.62 & 11.34 & 3.34 & 4.67 & 99.31 & 136.34 & 84.67 & 123.27 \\
\hline & Middle & 193.35 & 29.3 & 18.34 & 8.32 & 2.35 & 114.20 & 152.01 & 54.30 & 81.64 \\
\hline & Old & 232.60 & 29.65 & 21.00 & 10.00 & 5.65 & 124.33 & 161.22 & 27.50 & 39.76 \\
\hline \multirow[t]{3}{*}{ Hy-3C (MR) } & Young & 119.68 & 16.34 & 10.51 & 2.34 & 2.00 & 104.30 & 152.40 & 147.60 & 263.16 \\
\hline & Middle & 164.62 & 19.67 & 15.00 & 4.35 & 2.66 & 156.02 & 172.00 & 67.00 & 90.34 \\
\hline & Old & 231.01 & 23.34 & 19.34 & 6.33 & 4.65 & 178.00 & 182.10 & 35.10 & 65.33 \\
\hline \multirow[t]{3}{*}{ ICP 2376(S) } & Young & 80.20 & 15.33 & 7.33 & 2.06 & 0.67 & 115.34 & 157.00 & 276.33 & 421.44 \\
\hline & Middle & 156.34 & 17.01 & 11.34 & 4.35 & 2.34 & 128.31 & 179.30 & 178.60 & 243.53 \\
\hline & Old & 208.64 & 23.31 & 8.67 & 6.33 & 3.00 & 151.63 & 232.41 & 135.70 & 167.70 \\
\hline \multirow[t]{3}{*}{ ICP 8863(S) } & Young & 79.35 & 12.67 & 9.02 & 2.01 & 1.00 & 121.60 & 183.60 & 216.00 & 302.84 \\
\hline & Middle & 163.00 & 20.00 & 10.34 & 3.00 & 2.66 & 156.66 & 188.71 & 270.35 & 219.26 \\
\hline & Old & 219.65 & 23.02 & 11.66 & 6.00 & 3.48 & 181.20 & 254.10 & 126.65 & 151.73 \\
\hline \multirow[t]{5}{*}{ TTB-7 (S) } & Young & 103.32 & 14.33 & 8.67 & 1.67 & 0.34 & 115.02 & 153.00 & 272.30 & 501.43 \\
\hline & Middle & 158.60 & 19.67 & 13.00 & 4.00 & 2.00 & 125.14 & 177.70 & 180.30 & 349.14 \\
\hline & Old & 221.66 & 22.65 & 14.34 & 5.66 & 3.00 & 151.00 & 230.00 & 138.71 & 130.84 \\
\hline & SEM \pm & 1.21 & 0.74 & 0.59 & 0.47 & 0.43 & 1.15 & 1.56 & 1.41 & 2.22 \\
\hline & $\mathrm{CD}(\%)$ & 3.49 & 2.13 & 1.70 & 1.38 & 1.24 & 3.32 & 4.52 & 4.08 & 3.78 \\
\hline
\end{tabular}

and susceptible cultivars. Maximum thickness of cuticle of upper epidermis was found in the resistant cultivar ICP 7035. The young, middle and older leaves recorded $3.34 \mu \mathrm{m}, 8.32 \mu \mathrm{m}$ and $10.00 \mu \mathrm{m}$ of epidermal thickness, respectively and it was minimum in young leaves of TTB-7 $(1.67 \mu \mathrm{m})$, middle leaves of ICP $8863(3.00 \mu \mathrm{m})$ and older leaves of TTB-7 $(5.66 \mu \mathrm{m})$. However, in susceptible cultivar (TTB 7) less thickness of lower epidermal cuticle was recorded. All the three category leaves viz., young $(0.34 \mu \mathrm{m})$, middle $(2.00 \mu \mathrm{m})$ and old leaves $(3.00 \mu \mathrm{m})$ recorded lower thickness in TTB 7 as compared to resistant cultivars (Table 1).

The maximum leaf thickness in young, middle and old leaves was found in sterility mosaic disease resistant cultivar ICP7035 and minimum in susceptible cultivar ICP 8863. Interestingly, the field resistant cultivar viz., ICP 7035 and $\mathrm{HY} 3 \mathrm{C}$ had relatively thicker leaves and cuticle (3-8 times higher) as compared to susceptible cultivars viz., ICP 8863 and TTB 7. Seki (2016) reported that in carnations, cultivar associated with a thicker upper surface of tissue reduced the natural increase of the mites and thickness of internal leaf structure was also a factor for determining resistance to mites. In a similar study, Reddy et al. (1995) found that the leaf cuticle thickness was 50-100\% thicker in sterility mosaic disease resistant lines than in susceptible lines. Thus, it is clear that resistance shown by the cultivar viz., ICP 7035 was due to thick cuticle, epidermal cell wall and low density of hair, and may not be due to its resistance to the virus. Many workers have reported that the resistant lines seldom supported the continued mite multiplication (Nene et al., 1989). In susceptible lines, the mites are probably able to feed, multiply and transmit the virus as their stylets are long enough to pierce through leaf cuticle and reach the epidermal cell. Shorter stylet length (1-2 $\mu \mathrm{m})$ of mite complicates the feeding process on thick cuticle and epidermal cell wall. Prameela et al. (1990) reported that sterility mosaic infected pigeonpea plants had reduced thickness of leaf, epidermal and palisade cells in all cultivars irrespective of resistant or susceptible but more pronounced in susceptible cultivars than the resistant. The present findings is in confirmation with the previous study of Patil et al. (2017) where leaf morphological features such as thickness of lower and upper epidermis of leaves significantly differed between resistant and susceptible genotypes, and these traits might possibly be involved in vector mediated resistance against sterility mosaic disease.

In tested pigeonpea cultivars, significant differences were found in length and number of leaf hair in both upper and lower epidermis. The length of leaf hairs were minimum in leaves of upper surface of all the cultivars tested as compared to lower surface of leaves. The length of leaf hairs were maximum in lower surface of upper, middle and older leaves of ICP-8863 cultivar with length of $183.60 \mu \mathrm{m}, 188.71 \mu \mathrm{m}$ and $254.10 \mu \mathrm{m}$, respectively. However, minimum leaf hair length was observed in upper epidermis of ICP 7035 with $99.31 \mu \mathrm{m}, 114 \mu \mathrm{m}$ and 124.33 $\mu \mathrm{m}$ in all three category leaves (young, middle and old leaves), respectively. The length of leaf hairs in lower epidermis differed significantly between the resistant and susceptible cultivar. However, maximum length was recorded in the sterility mosaic disease susceptible variety ICP-8863 and minimum length on resistant cultivar ICP 7035 (Table 1). Number of leaf hairs in upper 
epidermis differed significantly between the cultivars. Maximum number of leaf hairs found in cultivars of ICP 2376 (276.33), ICP 8863 (270.35) and TTB-7 (138.71) compared to ICP 7035 (84.67, 54.30 and 27.50 leaf hairs/10 $\mu \mathrm{m}$ area) on young, middle and older leaves, respectively (Table 1). In lower epidermis, number of leaf hairs also differed significantly between cultivars with maximum on susceptible cultivar TTB-7 (501.43, 349.14 hairs on young, and middle leaves, respectively) as compared to resistant cultivar ICP 7035(123.27, 81.67 and 39.76 leaf hairs/10 $\mu \mathrm{m}$ sections, respectively).

The findings of the present study contradicts the results of Handley et al. (2005) where trichome density was negatively correlated with feeding, ovipositional behaviour and larval nutrition of large sized insect pests. Due to small and minute nature of mite vector, high density and length of trichomes allows the virus acquired vector to stay for longer time to feed and infect the virus into the plant system. Therefore, this would indirectly increase the disease incidence in genotypes containing higher density and length of trichome. Maluf et al. (2007) reported that glandular trichomes (especially type $\mathrm{VI}$ ) decreased the distances walked by the mites onto the tomato leaf surface. High density of leaf hair favours multiplication of the vector. Low density of leaf hair may not provide adequate microclimate required for Aceria cajani to multiply and withstand high wind currents due to its small size $(<250 \mu \mathrm{m})$. Therefore, low density of trichomes changes the micro climate of leaf by decreasing relative humidity and causing unfavourable conditions for breeding and fecundity of metes. Low density of leaf hairs in resistant cultivars might help in easy dispersal of mite vector by wind current before inoculating the virus into the plant; thereby adding to disease resistance mechanism. The number and length of glandular hairs supports the multiplication of eriophyid mites in tomato. Due to minute size of tomato russet mite (TRM) Aculops lycopersici (Acari: Eriophyidae) can seek refuge and feed in between the glandular trichomes and these trichome cover creates competitor-free and enemy-free space in tomato cultivars (Van Houten et al., 2013). Length of leaf hairs in lower epidermis of resistant cultivars was also less compared to length of leaf hairs in lower epidermis of susceptible cultivars. Because of this reason, the mite vector cannot hide in between the hair and are easily carried by wind currents before they inoculate the virus into the plant. Thus, the above parameters probably play an important role in preventing mite colonization, multiplication and occurrence of disease in the resistant cultivars. The plant surface which are devoid of glandular trichomes are highly prone to predation of mites than that on a plant surface with higher trichomes and these mites tends to seek refuge in the dense trichome, especially when there are predatory mites around (Simoni and Sabelis, 2010). The resistance against mite vector based on leaf morpho-anatomical traits such as thickness of cuticle, epidermal cells, more number and minimum length of trichomes, and older leaves are positively correlated with disease resistance. Leite et al. (1999) reported that high density of glandular trichomes found on wild type tomato can provide resistance against TRM.

In the present study, experimental inoculation of Pigeonpea sterility mosaic virus across different crop and weed species showed narrow host range in local plant community. Host range of the virus studied would help in formulating agronomic system in diseased localities and utilizing as a component in the integrated disease management. These components are essential in breeding for development of diverse and stable resistant cultivars against sterility mosaic disease. We also observed the degree of association of leaf morphological structures which are likely to be involved in resistance against mite vector feeding, fecundity in selected cultivars of pigeonpea, which can further be useful in the selection and development of broad based and stable resistant cultivars against sterility mosaic disease.

\section{Acknowledgments}

Authors are grateful to ICAR for providing Senior Research Fellowship for conducting this research, and also wish to express sincere thanks to Dr. Byre Gowda, AICRP (Pigeonpea) for their support and constant encouragement during the study.

\section{References}

Bhaskaran, K. and A.R. Muthiah: Screening and inheritance pattern of sterility mosaic disease resistance in pigeonpea. Indian J. Pulses Res., 18,124-126 (2005).

Durmuşkahya, C., A. Yurdanur and C. Ozdemir: Ecology, anatomy and morphology of Orchis spitzelii in Turkey. J. Env. Biol., 36, 177-184 (2015).

Elbeaino, T., A. Whitfield, M. Sharma and M. Digiaro: Emaravirus-specific degenerate PCR primers allowed the identification of partial RNA dependent-RNA polymerase sequences of maize red stripe virus and Pigeonpea Sterility Mosaic Virus. J. Virol Methods, 188, 37-40 (2013).

Elbeaino, T., M. Digiaro, M. Uppala and H. Sudini: Deep sequencing of pigeonpea sterility mosaic virus discloses five RNA segments related to Emaraviruses. Virus Res., 188, 27-31 (2014).

Elbeaino,T., M. Digiaro, M. Uppala and H. Sudini: Deep sequencing of dsRNAs recovered from mosaic-diseased pigeonpea reveals the presence of a novel Emaravirus: Pigeonpea Sterility Mosaic Virus 2. Arch Virol., 160, 2019-2029 (2015).

Farr, D.F., A.Y. Rossman, M.E. Palm and E.B. McCray: Fungus-host Distributions, Fungal Databases, Systematic Botany and Mycology Laboratory (Agric Res St/US Dep Agric) (2004). http://nt.ars-grin.gov/fungaldatabases/.

Farrell, B.D.: Evolutionary assembly of the milkweed fauna: cytochrome oxidase I and the age of Tetraopes beetles. Mol. Phylogenet. Evol., 18, 467-478 (2001).

Ghanekar, A.M., V.K. Sheila, S.P.S. Beniwal, M.V. Reddy and Y.L. Nene: Sterility mosaic of pigeonpea. In: Plant Diseases of International Importance. Diseases of cereals and pulses. (Eds.: U. S. Singh, A. N. Mukhopadhyay, J. Kumar and H. S. Chaube) Prentice Hall, New Jersey, Vol. 1, pp. 415-428(1992). 
Gucel, S.: Morphology, anatomy and cytology of critically endangered endemic Asperula daphneola from, West Anatolia, Turkey. J. Env. Biol., 36, 129-132 (2015).

Hall, D.G., E.D. Ammar, K.D. Bowman and E. Stover: Epifluorescence and stereomicroscopy of trichomes associated with resistant and susceptible host plant genotypes of the Asian citrus psyllid (Hemiptera: Liviidae), vector of citrus greening disease bacterium. J Microsc Ultrastruct (2017), http://dx.doi.org/10.1016/j.jmau. 2017.04.002

Handley, R., B. Ekbom and J. Agren: Variation in trichome density and resistance against a specialist insect herbivore in natural populations of Arabidopsis thaliana. Ecol. Entomol., 30, 28492(2005). doi: 10.1111/j.0307-6946.2005.00699.x.

Jones, A. T., P. L. Kumar, K. B. Saxena, N. K. Kulkarni, V. Muniyappa and F. Waliyar: Sterility mosaic disease- the "Green Plague" of pigeonpea, advances in understanding the etiology, transmission and control of a major virus disease. Plant Disease, 88, 436-445 (2004)

Kannaiyan, J., Y.L. Nene, M.V. Reddy, J.G. Ryan and T.N. Raju: Prevalence of pigeonpea diseases and associated crop losses in Asia, Africa and the Americas. Trop. Pest Manage., 30, 62-71 (1984)

Krips, O.E., P.W. Kleijn, P.E.L. Willems, G.J.Z. Gols and M. Dicke: Leaf hair influence searching efficiency and predation rate of the predatory mite Phytoseiulus persimilis (Phytoseiidae: Acarina). Exp. Appl. Acarol., 23, 119-131 (1999).

Kulkarni, N.K., A.S. Reddy, L.P. Kumar, J. Vijaynarasimha, K.T. Rangaswamy, V. Muniyappa, L.J. Reddy, K.B. Saxena, A.T. Jones and D.V.R. Reddy: Broad-based resistance to pigeonpea sterility mosaic disease in accessions of Cajanas scarabaeoides (L.) Benth. Indian J. Plant. Prot., 31, 6-11 (2003).

Kumar, P.L., A.T. Jones and D.V.R. Reddy: Mechanical transmission of Pigeonpea sterility mosaic virus. J. Mycol. PI. Pathol., 32, 8889(2002).

Leite, G.L.D., M. Picanco, R.N.C. Guedes and J.C. Zanuncio: Influence of canopy height and fertilization levels on the resistance of Lycopersicon hirsutum to Aculops lycopersici (Acari: Eriophyidae). Exp. Appl. Acarol., 23, 633-642 (1999).

Maluf, W.R., I. F. Inoue, R.D.P. D. Ferreira, L.A.A. Gomes, E.M.D. Castro and M.D.G. Cardoso: Higher glandular trichome density in tomato leaflets and repellence to spider mites. Pesq. agropec. bras., 42, 1227-1235(2007).

Mitra, M.: Report of the Imperial Mycologist. Sci. Rep. Agric. Res. Inst. Pusa, 19, 58-71(1931).

Muehlbach, H.P. and N. Mielke-Ehret: Genus Emaravirus. In: Virus Taxonomy (Eds.: A.M.Q. King, M.J. Adams, E.B. Carstend and E.J. Lefkowitz). Ninth Report of the International Committee on Taxonomy of Viruses. Elsevier/Academic Press, pp. 767-769 (2011).

Nene, Y.L., M.V. Reddy, S.P.S. Beniwal, M. Mahamood, K.K. Zote, R.N. Singh and K. Sivaprakasam: Multilocational testing of pigeonpea for broad based resistance to sterility mosaic. Indian Phytopath., 42, 444-448 (1989).
Packer, A. and K. Clay: Soil pathogens and spatial patterns of seedling mortality in a temperate tree. Nature, 404, 278-281 (2000).

Patil, P.G., H.E. Shashidhar, M. Byregowda, G.A.M. Reena, T.H. Ashok, H.V.V. Swamy, H.K. Ramappa and J. Babu: Association of leaf micro-morphological features with sterility mosaic virus disease resistance in pigeonpea. J. Environ. Biol., 38, 649-656 (2017).

Peter, A.J., T.G. Shanower and J. Romeis: The role of plant trichomes in insect resistance: A selective review. Phytopathology, 7, 41-63 (1995).

Prameela, H.A., S.S. Joshi, S. Vishwanath and T.B.A. Kumar: Histological and histochemical changes in pigeonpea due to single and dual infections by powdery mildew and sterility mosaic virus. Biochem. Physiol. Pflanzen., 186, 55-61(1990).

Reddy, M.V., K.C. Jain, Y.S. Chauhan and L. Singh: Wilt and sterility mosaic disease resistant pigeonpea genotype ICPL 87119 benefits farmers in Medak district of Andhra Pradesh, India. Int. Chickpea Pigeonpea Newsl., 2, 71-72(1995).

Reddy, M.V., S.B. Sharma and Y.L. Nene: Pigeonpea: Disease management. In: Pigeonpea (Eds.: Y.L. Nene, D. Susan, Hall and V.K. Sheila) CAB International, UK and ICRISAT, India, pp. 303316(1990).

Reddy, M.V., T.N Raju., Y.L. Nene., A.M. Ghanekar, K.S. Amin, G. Arjunan, J.V. Astaputre, B.K. Sinha, S.V. Reddy, R.P. Gupta and K. Gangadharan: Variability in sterility mosaic pathogen in pigeonpea in India. Indian Phytopath., 46, 206-212(1993).

Reddy, M.V., T.N. Raju and J.M. Lenne: Diseases of pigeonpea. In: The Pathology of Food and Pasture Legumes (Eds.: D.J. Allen and J. M. Lenne). CAB International ICRISAT, pp. 517-558 (1998).

Ruzin, S.E.: Plant microtechnique and microscopy. New York, Oxford University Press (1999).

Seki, K.: Leaf-morphology-assisted selection for resistance to twospotted spider mite Tetranychus urticae Koch (Acari: Tetranychidae) in carnations (Dianthus caryophyllus L). Pest Manag Sci., 72, 1926-1933 (2016).

Seth, M.L.: Transmission of pigeonpea sterility by an eriophyid mite. Indian Phytopath., 15, 225-227(1962).

Sharma, M., R. Ghosh and S. Pande: Multi-environment field testing to identify broad, stable resistance to sterility mosaic disease of pigeonpea. J. Gen. Plant Pathol., 81, 249-259(2015).

Simoni, S. and M.W. Sabelis: Glandular trichome 'forests' on tomato leaves act as a predation refuge for tomato russet mites. Recife: Abstracts XII International Congress of Acarology, (2010).

Singh, A.K. and Y.P.S. Rathi: Nature of losses caused by sterility mosaic in pigeonpea. J. Appl. Biol., 4, 35-37(1994).

Thompson, J.N.: The Geographic Mosaic of Co-evolution (Univ of Chicago Press, Chicago) (2005).

Van Houten, Y.M., J.J. Glas, H. Hoogerbrugge, J. Rothe, K.J.F. Bolckmans, S. Simoni, J. van Arkel, J.M. Alba, M.R. Kant and M.W. Sabelis: Herbivory-associated degradation of tomato trichomes and its impact on biological control of Aculops lycopersici. Exp. Appl. Acarol., 60, 127-138 (2013). DOI 10.1007/s10493-0129638-6 